Article

\title{
The Reliability of Global Remote Sensing Evapotranspiration Products over Amazon
}

\author{
Jie Wu ${ }^{1}$, Venkataraman Lakshmi ${ }^{2}$, Dashan Wang ${ }^{1}{ }^{\circledR}$, Peirong Lin $^{3}$, Ming Pan ${ }^{3}{ }^{\circledR}$, Xitian Cai ${ }^{4}$, \\ Eric F. Wood ${ }^{3}$ and Zhenzhong Zeng ${ }^{1, *}$ \\ 1 School of Environmental Science and Engineering, Southern University of Science and Technology, \\ Shenzhen 518055, China; wuj6@mail.sustech.edu.cn (J.W.); wangds6@sustech.edu.cn (D.W.) \\ 2 Department of Engineering Systems and Environment, University of Virginia, Charlottesville, \\ VA 22904, USA; vlakshmi@virginia.edu \\ 3 Department of Civil and Environmental Engineering, Princeton University, Princeton, NJ 08544, USA; \\ peirong1@princeton.edu (P.L.); mpan@princeton.edu (M.P.); efwood@princeton.edu (E.F.W.) \\ 4 Climate and Ecosystem Sciences Division, Lawrence Berkeley National Laboratory, Berkeley, CA 94720, USA; \\ xtcai@lbl.gov \\ * Correspondence: zzeng@princeton.edu
}

Received: 11 May 2020; Accepted: 8 July 2020; Published: 10 July 2020

\begin{abstract}
As a key component of terrestrial water cycle, evapotranspiration (ET), specifically over the Amazon River basin, is of high scientific significance. However, due to the sparse observation network and relatively short observational period of eddy covariance data, large uncertainties remain in the spatial-temporal characteristics of ET over the Amazon. Recently, a great number of long-term global remotely sensed ET products have been developed to fill the observation gap. However, the reliabilities of these global ET products over the Amazon are unknown. In this study, we assessed the consistency of the magnitude, trend and spatial pattern of Amazon ET among five global remotely sensed ET reconstructions. The magnitudes of these products are similar but the long-term trends from 1982 to 2011 are completely divergent. Validation from the eddy covariance data and water balance method proves a better performance of a product grounded on local measurements, highlighting the importance of local measurements in the ET reconstruction. We also examined four hypotheses dealing with the response of ET to brightening, warming, greening and deforestation, which shows that in general, these ET products respond better to warming and greening than to brightening and deforestation. This large uncertainty highlights the need for future studies focusing on ET issues over the Amazon.
\end{abstract}

Keywords: evapotranspiration; global product; Amazon; consistency; response; deforestation

\section{Introduction}

Evapotranspiration (ET), the exchange of water vapor between the land surface and atmosphere through diffusion, plays a central role in the climate system and connects water, energy and carbon cycles [1,2]. One of the major sources of global terrestrial ET is the Amazon forests and savannas [3], which has the capacity to regulate the global climate through biogeophysical and biogeochemical feedbacks. Amazon ET affects not only regional, but also the global climate patterns [4]. Thus, an accurate estimation of ET in the Amazon River basin is of high scientific significance.

Several methods have been utilized to estimate ET [5,6]. Among them, the eddy covariance (EC) method is regarded as one of the best methods for direct latent heat flux measurement, but the observation network is sparse and the spanning period is relatively short [5]. The water balance method (WB) is direct and simple $[7,8]$, but it cannot reflect the spatial variability of ET at a fine scale. 
To fill the observation gap, remote sensing technologies were utilized to describe the spatial variability and magnitude of ET with acceptable accuracy [9]. There are other methods that use a combination of modeling and remote sensing [10-12] that hold promise. Direct observations from EC, WB and other remote sensing variables are integrated with machine learning and/or land surface models to reconstruct grid-scale long-term global ET products [13], including but not limited to MOD16, JUN10, ZEN14, ZHA15, ZHA16 and GLEAM. By merging ET derived from diagnostic data sets or calculated by land-surface models, LandFlux-EVAL is considered a global benchmark product for terrestrial ET [14]. However, whether these global remote sensing ET reconstructions are reliable over the Amazon River basin is open to doubt. Previous studies revealed large uncertainties in the ET estimates over the Amazon River basin. In situ measurements of ET from the Large-Scale Biosphere-Atmosphere Experiment in the Amazon (LBA) range from 2.7 to $6.0 \mathrm{~mm} /$ day ( 986 to $2190 \mathrm{~mm} /$ year) [15]. Estimates of basin-scale mean annual ET reported by multiple process-based models, such as ERA-40, NCEP-NCAR and NASA GEOS-1 reanalysis gridded evaporation products, are in the range of 3.5 to $4.6 \mathrm{~mm} /$ day (1278 to $1679 \mathrm{~mm} /$ year) [16-18]. The uncertainties regarding the spatial-temporal changes of ET over the Amazon are even larger, but have not been evaluated yet.

Apart from the consistency, the capabilities of the global remote sensing products to reflect ET response to various drivers are still uncertain. During the past decades, global warming and increasing anthropogenic activities have accelerated the global water cycle [19], which inevitably altered ET [20], whose components (plant transpiration $\left(E_{t}\right)$, soil evaporation $\left(E_{s}\right)$ and canopy interception $\left.\left(E_{i}\right)\right)$, respond differently to changing environmental and/or vegetation conditions [21]. There have been several hypotheses concerning how ET in the Amazon varies under changing conditions. First, in the context of global warming, Amazon ET is expected to increase because atmospheric evaporative demand, the determinant of ET, is going to increase with rising air temperature [5]. The second is net radiation, the primary determinant of ET in the Amazon basin [22]. Researchers have reported a widespread increase in surface solar radiation (brightening) since the late 1980s [23]. In addition, it is well-known that deforestation has been occurring in the Amazon River basin over the past three decades [24,25], which would decrease ET, because deforestation reduces transpiration $\left(E_{t}\right)$. Finally, despite deforestation in the Amazon River basin, the regional leaf area index (LAI) has increased during the same period, indicating greening in the region [26-28]. Greening might have opposite effects on ET compared to deforestation.

In this study, eddy covariance data and water balance approach are jointly used to investigate the reliability of the five published global remote sensing ET products (JUN10, ZEN14, ZHA15, ZHA16 and GLEAM) (Table 1) in their ET estimates over the Amazon River basin [1,20,21,29-31]. The objectives of this study are to: (1) Assess the consistency of ET estimates by five global ET reconstructions in terms of magnitude and spatial-temporal characteristics; (2) Compare the capabilities of these products to reflect the ET response to different drivers (brightening, warming, greening and deforestation) over the Amazon River basin. 
Table 1. Description of the five global remote sensing evapotranspiration (ET) reconstructions in this study.

\begin{tabular}{|c|c|c|c|c|c|c|}
\hline Product & Algorithm & $\begin{array}{l}\text { Ground-based } \\
\text { Measurements }\end{array}$ & Drivers & $\begin{array}{c}\text { Spatial } \\
\text { Resolution }\end{array}$ & $\begin{array}{c}\text { Temporal } \\
\text { Resolution }\end{array}$ & Period \\
\hline JUN10 & $\begin{array}{l}\text { Machine } \\
\text { learning } \\
\text { (MTE) }\end{array}$ & EC & $P, T_{a}, f A P A R$ & $0.5^{\circ} \times 0.5^{\circ}$ & monthly & 1982-2011 \\
\hline ZEN14 & $\begin{array}{l}\text { Machine } \\
\text { learning } \\
\text { (MTE) }\end{array}$ & WB & $\begin{array}{c}P, T_{a}, R, P S, V_{p} \\
W, F_{w}, F_{f} \\
N D V I\end{array}$ & $0.5^{\circ} \times 0.5^{\circ}$ & monthly & 1982-2013 \\
\hline ZHA15 & P-LSH & - & $\begin{array}{c}\mathrm{Ta}, \mathrm{R}, V_{p}, W \\
\mathrm{CO}_{2}, \mathrm{NDVI}\end{array}$ & $8 \mathrm{~km} \times 8 \mathrm{~km}$ & monthly & 1982-2013 \\
\hline ZHA16 & $\begin{array}{l}\text { PML model } \\
\text { Gash model }\end{array}$ & $\begin{array}{l}\text { WB, EC, field } \\
\text { experiments for } \\
\text { validation }\end{array}$ & $\begin{array}{l}P, T_{a}, V_{p}, R, W \\
\quad L A I, V_{e}, V_{a}\end{array}$ & $0.5^{\circ} \times 0.5^{\circ}$ & monthly & 1981-2012 \\
\hline GLEAM & $\begin{array}{l}\text { Revised } \\
\text { Priestley-Taylor } \\
\text { Equation }\end{array}$ & $\begin{array}{c}\text { EC, soil } \\
\text { moisture sensors } \\
\text { for validation }\end{array}$ & $\begin{array}{c}R, P, T_{a}, S W E \\
V O D, S M\end{array}$ & $0.25^{\circ} \times 0.25^{\circ}$ & daily & 1980-2012 \\
\hline
\end{tabular}

\section{Materials and Methods}

\subsection{Five Long-Term Global Remote Sensing ET Products Covering the Period 1982 to 2011}

Five global remote sensing ET products, i.e., JUN10, ZEN14, ZHA15, ZHA16, and GLEAM, were used in this study (Table 1). These five products were chosen for comparison because of their longer spanning period (from 1982 to 2011), while other products, such as LandFlux-EVAL and MOD16, can not cover a period as long as 30 years [14,32].

JUN10 is a data-driven monthly ET product at a $0.5^{\circ}$ resolution from 1982 to 2008 [1]. It integrated ET measurements from the FLUXNET global network with surface meteorological records and satellite remote sensing observations in a machine learning method (the model tree ensemble, MTE). In the reconstruction, precipitation $(P)$, air temperature $\left(T_{a}\right)$ and the fraction of absorbed photosynthetically active radiation $(f A P A R)$ were used as the explanatory variables. Similar to JUN 10, ZEN14 is also a machine-learning-based ET product, but it is coupled a WB model [29]. Specifically, by combining basin-scale averaged ET estimates from the Gravity Recovery and Climate Experiment (GRACE) with the potential drivers $\left(P, T a\right.$, radiation $(R)$, pressure $(P S)$, vapor pressure $\left(V_{p}\right)$, wind speed $(W)$, wet day frequency $\left(F_{w}\right)$, frost day frequency $\left(F_{f}\right)$ and Normalized Difference Vegetation Index $\left.(N D V I)\right)$, ZEN14 established a monthly ET product with a spatial resolution of $0.5^{\circ}$ between 1982 and 2009. In this study, the updated versions of JUN10 (spanning from 1982 to 2011) and ZEN14 (1982-2013) were utilized.

Different from data-driven ET products like JUN10 and ZEN14, ZHA15, ZHA16 and GLEAM combined process-based algorithms with observations. ZHA15 applied a remote-sensing-driven ET algorithm, i.e., the Process-based Land Surface Evapotranspiration/Heat Fluxes algorithm (P-LSH) [20]. P-LSH is an improvement of the Penman-Monteith (PM) approach by taking the influence of changing wind speed and variable atmospheric $\mathrm{CO}_{2}$ concentrations into account. The dataset used in this study is at eight-kilometer resolution from 1982-2013. Based on the Penman-Monteith-Leuning (PML) model, ZHA16 produced actual ET and its two components $\left(E_{t}\right.$ and $\left.E_{s}\right)$ at a $0.5^{\circ}$ spatial resolution during the period 1981-2012 [21]. The rest component, $\mathrm{E}_{\mathrm{i}}$, is modelled using the Gash rainfall interception model. Emissivity $\left(V_{e}\right)$ and albedo $\left(V_{a}\right)$ are also used as forcing data in this product. GLEAM (Global Land surface Evaporation: the Amsterdam Methodology) estimated global daily evaporation by combining a variety of satellite products [30,31]. The use of the revised Priestley-Taylor (PT) equation, which depends only on two inputs (net radiation (Rn) and air temperature), reduces the number of model variables. To objectively compare these products, all datasets were resampled to $0.25^{\circ}$ spatially and the study period was limited to 1982-2011. 


\subsection{Eddy Covariance Data}

To validate the different remote sensing products at site scale and to investigate the ET response to deforestation, EC data from two sources were used (Figure 1 and Table 2). The first one is the LBA-ECO CD-32 Flux Tower Network Data Compilation (Brazilian Amazon: 1999-2006), provided by independent investigators after automated and manual quality control [33]. Four sites, i.e., tropical rainforest site K34, tropical moist forest site K67, tropical dry forest site RJA and pasture site FNS, were chosen in this study. The data are monthly with some missing values, so the annual ET was calculated as the sum of the average monthly ET. When assessing the accuracy of each model at site level using EC data, only the months with EC data were compared, as we do not fill the gap. We also gathered an annual ET record of Sinop site from Vourlitis et al. [34]. The site is located in the semi-deciduous forest in Brazil and the annual record spans from 2000 to 2006.

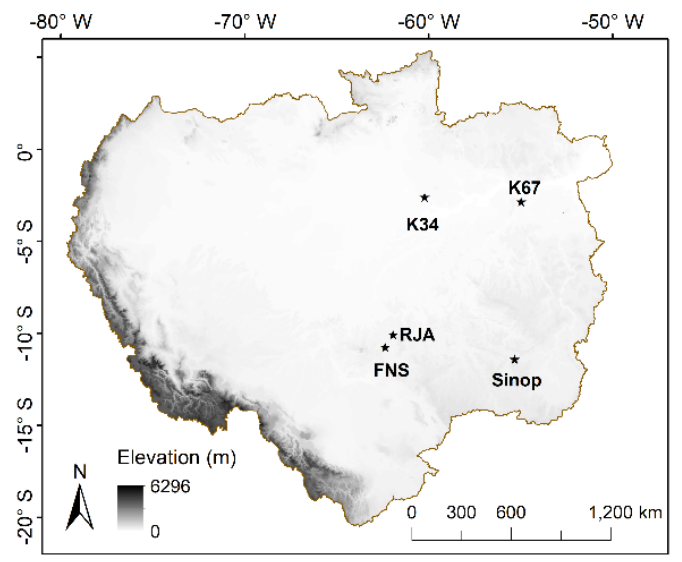

Figure 1. Locations of the five tropical eddy covariance sites in the Amazon.

Table 2. Main characteristics of the five sites in the study.

\begin{tabular}{ccccc}
\hline Site name & $\begin{array}{c}\text { Vegetation } \\
\text { Description }\end{array}$ & Latitude & Longitude & Period of Data used \\
\hline Santarém km 67 (K67) & Tropical Moist Forest & $2.86^{\circ} \mathrm{S}$ & $54.96^{\circ} \mathrm{W}$ & Jan 2002-Jan 2006 \\
Manaus KM34 (K34) & Tropical Rainforest & $2.61^{\circ} \mathrm{S}$ & $60.21^{\circ} \mathrm{W}$ & Jul 1999-Oct 2006 \\
Reserva Jaru (RJA) & Tropical Dry Forest & $10.08^{\circ} \mathrm{S}$ & $61.93^{\circ} \mathrm{W}$ & Mar 1999-Nov 2002 \\
Fazenda Nossa Senhora (FNS) & Pasture & $10.76^{\circ} \mathrm{S}$ & $62.36^{\circ} \mathrm{W}$ & Feb 1999-Mar 2002 \\
Sinop-Mato Grosso (Sinop) & Semi-deciduous Forest & $11.41^{\circ} \mathrm{S}$ & $55.32^{\circ} \mathrm{W}$ & 2000-2006 \\
\hline
\end{tabular}

\subsection{Evapotranspiration Calculation Using Water Balance Method}

To assess the magnitude of ET estimated by the five remote sensing ET products at watershed level, the WB method was used to calculates ET as

$$
E T=P-Q-d w / d t
$$

where $P$ is precipitation, $Q$ is the measured discharge, and $d w / d t$ is the terrestrial water storage change (TWSC). In the long term, TWSC is negligible for average annual ET at basin scale [6], and Equation (1) can be simplified as $E T=P-R$. The average annual ET for a watershed is thus calculated as the residual between mean annual precipitation and runoff (P minus $Q)$.

In this study, precipitation is estimated using two datasets. Firstly, the Global Precipitation Measurement (GPM) IMERG V06 product from NASA was used (https:/pmm.nasa.gov/data-access/ downloads/gpm). Based on the success of the Tropical Rainfall Measuring Mission (TRMM) [35], this new generation of GPM precipitation products features higher precision, larger coverage area and higher spatial and temporal resolution through improvements in the precipitation measurements world-wide. However, the precipitation data provided by GPM only starts from 2000, which does 
not cover the whole research period. As an alternative, the Global Precipitation Climatology Center (GPCC) 0.5-grided Full Data Product was used (https://climatedataguide.ucar.edu/climate-data/gpccglobal-precipitation-climatology-centre) [36]. This product provides monthly gridded precipitation data for the period 1891 to 2016, which is derived from 67,200 stations globally with a record duration of at least 10 years $[37,38]$. However, GPCC data also has a limitation. The number of stations in each grid in GPCC is variable over time and can be a major inhomogeneity source. In order to make full use of these two datasets, the GPCC dataset is mainly used in this study, while the GPM dataset was utilized to validate the quality of the GPCC product. Specifically, the annual precipitation between the year 2002 and 2012 from both GPM and GPCC were compared. As shown in Figure 2a, these two datasets have good correlation, with $\mathrm{R}^{2}$ of 0.995 , which enables the reconstruction of GPM-based annual precipitation between 1982 and 1999.
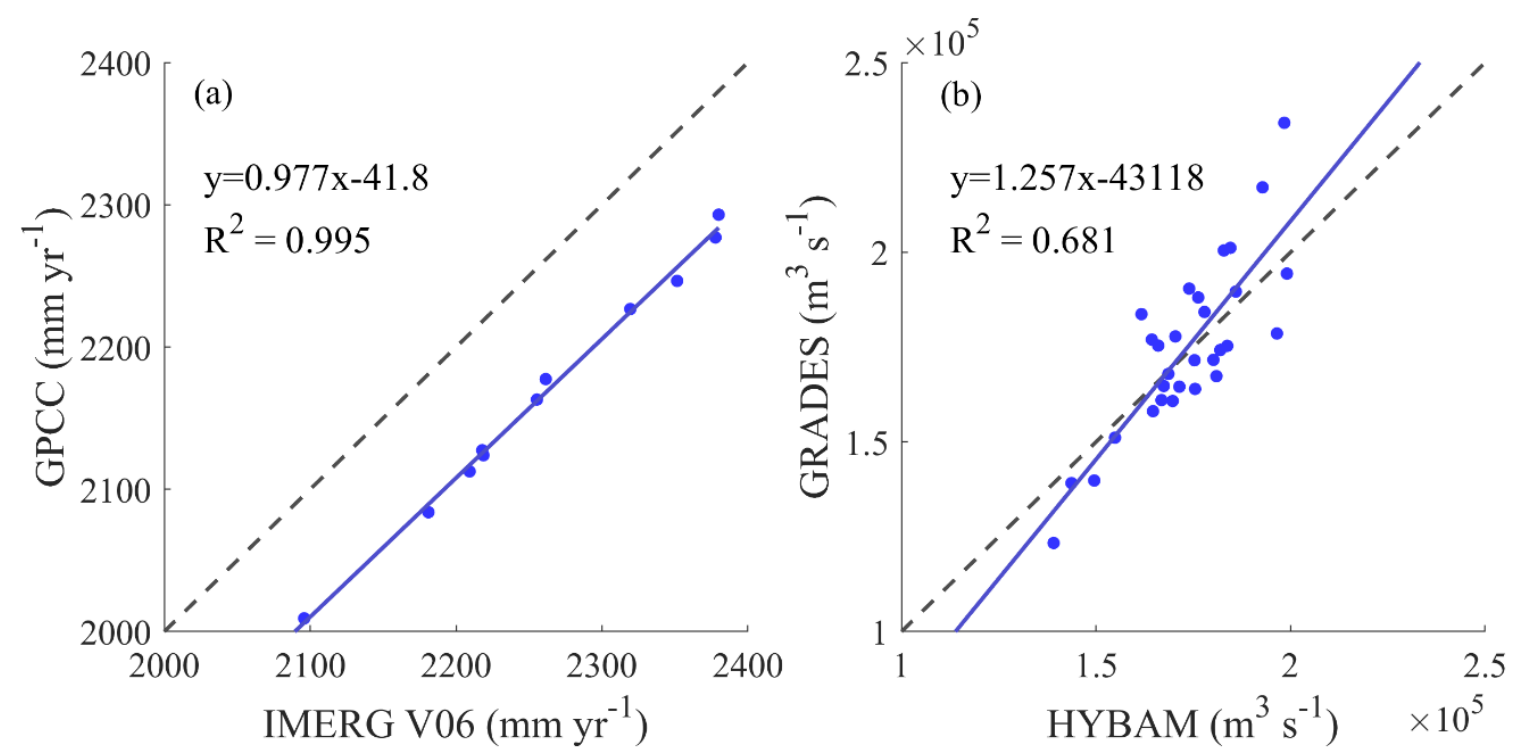

Figure 2. (a) Annual precipitation from Global Precipitation Measurement IMERG V06 (IMERG V06) vs. precipitation from Global Precipitation Climatology Center (GPCC). (b) Gauged annual discharge from HYBAM vs. annual discharge from Global Reach-level A priori Discharge Estimates for Surface Water and Ocean Topography (GRADES). The solid line represents the linear regression and the dash line is the 1:1 line.

In terms of discharge, due to a lack of in situ discharge measurements at the downstream of the Amazon River, it is difficult to directly determine the discharge of the whole basin. As an alternative, a reconstructed discharge record, Global Reach-level A priori Discharge Estimates for Surface Water and Ocean Topography (GRADES), is used [39]. GRADES estimates global river discharge at 2.94 million reaches at very high resolutions, and the estimates were constrained by thousands of gauge observations globally. In order to validate the accuracy of the GRADES discharge estimates, we first made a comparison between the gauged and modeled discharge over the Obidos sub-basin, where the measured discharge is available. Discharge data from Obidos, the control gauging station of the upstream stream, is from SO HYBAM (http://www.ore-hybam.org/index.php/eng/Data). As shown in Figure $2 b$, the $R^{2}$ is 0.681 , demonstrating the robustness of the data record for use in the Amazon River basin. Therefore, after the validation, we expanded the use of the GRADES discharge to the whole basin.

\subsection{Climate Drivers of ET}

Two climate drivers were analyzed in this study.

Most parts of the Amazon are energy-limited and ET is highly correlated with Rn [1,22]. Since ET is part of Rn, we wouldn't call Rn a "direct" driver. Instead, downward shortwave is considered as 
a "driver". In this study, monthly averaged surface net solar radiation data is from ERA5-Land [40], a reanalysis dataset that provides a detailed record of land variables (https://cds.climate.copernicus.eu/).

Besides, atmospheric evaporative demand is affected by radiation, humidity, air temperature, and wind speed [41]. Given the availability of data, air temperature is chosen to reflect the response of ET to atmospheric evaporative demand. In this study, gridded monthly air temperature data $\left(0.5^{\circ} \times 0.5^{\circ}\right)$ is from the Climatic Research Unit (CRU) [42] (http://badc.nerc.ac.uk/data/cru/).

\subsection{Vegetation Greenness Proxy}

Vegetation is an important determinant of ET. In this work, LAI, the ratio of the total leaf area of plants to the land area on a certain land area, is chosen to reflect the vegetation condition [43]. It is often utilized to describe the vegetation canopy structure, especially in the Amazon River basin, as it controls various biological and physical processes of vegetation. LAI data from 1982 to 2011 were obtained from Zhu et al. [44]. It was based on GIMMS_LAI-FPAR3g version 2 product. The resolution for this dataset is monthly temporally and eight kilometers spatially.

\subsection{Land Cover Change}

Due to the increasing urbanization and agricultural development, the maintenance of the Amazon forests is threatened by the land cover change during the past 30 years. This kind of conversion from "forest" into "non-forest" is known as deforestation [45]. To reflect the land cover change during the past 30 years in the Amazon River basin, we chose the ESA-CCI-LC data, which is provided by the Climate Change Initiative (CCI) lead by the Europe Space Agency (ESA). Consistent annual global land cover (LC) maps at a $300 \mathrm{~m}$ spatial resolution from 1992 to 2015 were delivered by the CCI-LC project [46]. The core of the deforestation research is the definition of forest. In this study, regions with the class code $50,60,61,62,70,71,72,80,81,82,90,100,160$ or 170 were defined as forest areas according to the legend system. The land cover condition in the year 2011 was then compared with that in 1992. If the percentage of forest in a pixel (resampled to $0.25^{\circ} \times 0.25^{\circ}$ ) decreased by $20 \%$, then the pixel is defined as deforestation.

To investigate the ET response to changing environment and/or vegetation conditions, ET over the regions with and without change are compared. In the definition of regions with significant change in a certain driver (i.e., surface net solar radiation, temperature and LAI), a robust multi-linear regression and the Mann-Kendall (MK) non-parametric test were used to estimate and test the temporal trends $[47,48]$. To remove the geographical impacts, we calculated the ET values over the corresponding buffer zone of the changed region. The buffer zone is a neighboring region with a similar size and, on average, the same latitude, so that the comparison is reasonable.

\section{Results and Discussions}

\subsection{Validation of the Global Remote Sensing ET Products}

\subsubsection{Validation Using Eddy Covariance Data at Site Level}

To validate the five long-term global remote sensing ET products, ET estimates over the pixels where the EC sites are located were extracted from the five products and compared with the ground-truth data from four EC sites (Figure 3). In general, the performances of these ET products are better over the forest sites, as most of the ET estimates are in the uncertainty range of ground-observed ET over site $\mathrm{K} 34, \mathrm{~K} 67$ and RJA, while all the ET estimates are overestimated by the five products over the pasture site FNS. 

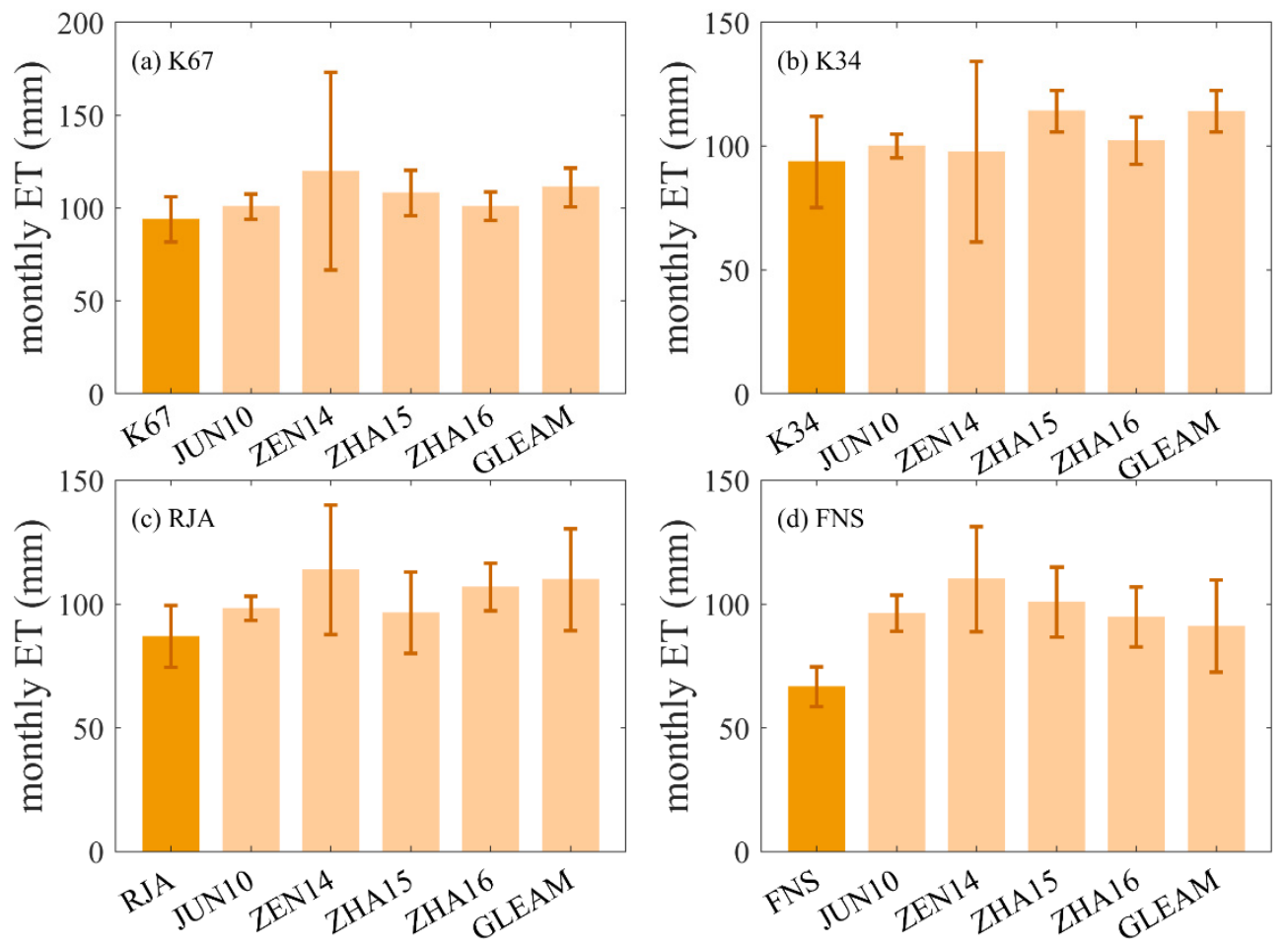

Figure 3. Comparison of monthly ET magnitude and variability from four eddy covariance sites in the Amazon River basin: (a) Santarém km 67 (K67) (b) Manaus KM34 (K34) (c) Reserva Jaru (RJA) and (d) Fazenda Nossa Senhora (FNS) and ET estimates from five products at pixel level.

Over the three forest sites, JUN10 has the best performance with all the ET estimates within the uncertainty range, followed by ZHA16 (two sites) and ZHA15 (one site). By contrast, ZEN14 and GLEAM tend to overestimate ET. This discrepancy is associated with the algorithm and ground-based measurements used by various products. JUN10 combines EC data in the reconstruction and ZHA16 used EC data for validation, while ZEN14 is based on WB method. As for the variability, JUN10 has largely underestimated the variation while ZEN14 overestimated it.

\subsubsection{Validation Using Water Balance Method at Watershed Scale}

Average annual ET (1982-2011) over the whole Amazon basin were reconstructed by five products (Figure 4). The largest annual ET was reported by GLEAM, up to $1270 \pm 22 \mathrm{~mm} /$ year, followed by ZHA15 (1255 $\pm 18 \mathrm{~mm} /$ year) and ZEN14 (1239 $\pm 82 \mathrm{~mm} /$ year). ZHA16 and JUN10 produced a relatively lower estimate, $1164 \pm 28 \mathrm{~mm} /$ year and $1113 \pm 10 \mathrm{~mm} /$ year. The arithmetic mean of the annual ET over the Amazon from 1982 to 2011 reported by these five products is $1208 \mathrm{~mm} /$ year. This estimate agrees well with the previous studies, which reported a mean annual ET of 767-1642 mm/year over the entire Amazon River basin [49].

The result is relatively higher than the magnitude produced by the WB method. In this study, the multi-year (1982-2011) average input of water through rainfall is $2249 \mathrm{~mm} / \mathrm{year}$ and the output is $1119 \mathrm{~mm} /$ year, so the estimated basin-scale annual ET is $1130 \mathrm{~mm} /$ year. According to Zhang et al., Amazon ET is around $1153 \mathrm{~mm} /$ year and rainfall is about 2160-2182 mm/year during the period 1984-2010 [50]; Pan et al. estimated the Amazon ET to be around $1145 \mathrm{~mm} /$ year and rainfall $2173 \mathrm{~mm} /$ year between 1984 and 2006 [51]. It seems that JUN10 and ZHA16 have better performance in the magnitude estimation. The former also performs well at site level. ZHA16 produces a lower ET estimate that is close to the WB-based magnitude because it considers the WB based ET estimates over Amazon. It should be noted that even though it is based on WB, ZEN14 still overestimates ET over the Amazon. 


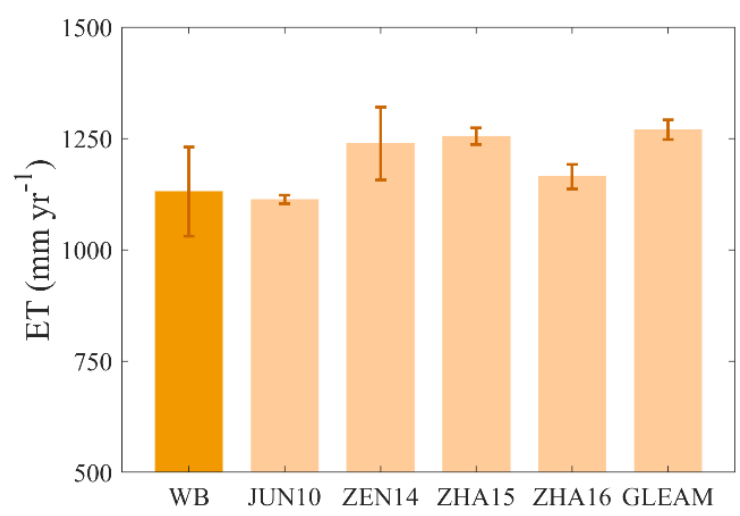

Figure 4. Comparison of annual ET magnitude from water balance method and from five products at basin scale.

\subsection{Changes of ET for 1982-2011 from the Global Remote Sensing ET Products}

\subsubsection{Inconsistent Estimates of the Trend of ET}

Despite the similar magnitudes, the multi-year (1982-2011) ET trends estimated by five remote sensing products over the Amazon River basin lack consistency (Figure 5a). The maximum rate of increase in ET was reported by ZEN14, up to $76.4 \mathrm{~mm} /$ year per decade, followed by ZHA15 $(9.0 \mathrm{~mm} /$ year/decade). Both of these upward trends were statistically significant $(P<0.05)$. By contrast, GLEAM reported a significant ET decrease, up to $-21.2 \mathrm{~mm} /$ year per decade. JUN10 also estimated a downward trend, although it is not statistically significant. It is interesting to see that the trend reported by ZHA16 is completely different from others. During the period of 1982 to 1998, ET over the Amazon River basin increased dramatically, with a linear trend of $49.6 \mathrm{~mm} / \mathrm{year}$ per decade. However, a turning point appeared in 1998. After that, ET began to drop significantly ( $35.0 \mathrm{~mm} /$ year/decade).

\subsubsection{Spatial Pattern of ET}

The spatial distribution of the multiyear (1982-2011) average annual ET from the five global ET products is shown in Figure 5. As can be seen from the figure, there are some similarities among the estimates of ET from the five products. Nearly all products reported the lowest annual mean ET alongside the southwest of the Amazon River basin. In addition, for each product, the highest annual ET occurs in the areas near the equator, specifically, between $5^{\circ} \mathrm{N}$ and $5^{\circ} \mathrm{S}$. However, it is clear to see that large discrepancies exist in the spatial pattern of the multiyear average annual ET. In general, ET estimates from ZEN14 and GLEAM are higher than those from the other three (JUN10, ZHA15 and ZHA16). These two products also show large spatial heterogeneity over the whole basin, whereas ET presented by the other three products were more evenly distributed in space. It should be noted that ZEN14 produced a high estimate of ET (above $1400 \mathrm{~mm} /$ year) in the southeast of the Amazon River basin, which is quite different from the results from other products. 


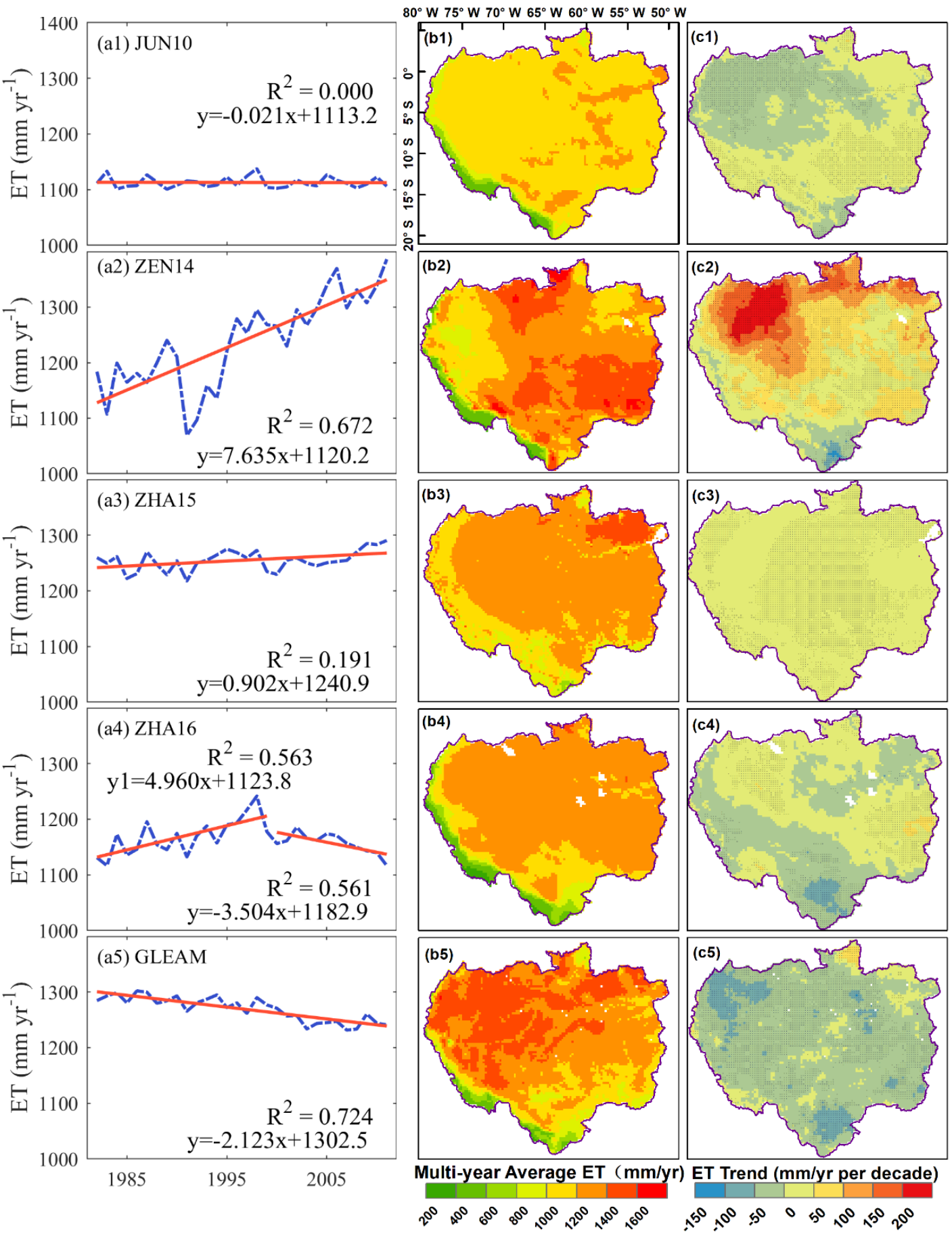

Figure 5. Basin-average multi-year trend of ET(a1-a5), spatial pattern of multi-year average ET(b1-b5) and ET trends (c1-c5) between the period 1982-2011 in the Amazon River basin from (1) JUN10, (2) ZEN14, (3) ZHA15, (4) ZHA16, and (5) GLEAM. Details of the five products can be found in Table 1. Dots in $(\mathbf{c} 1-\mathbf{c} 5)$ represent significant trend $(P<0.05)$.

\subsubsection{Spatial Pattern of ET Trend}

In terms of the spatial distribution of ET trends, both similarities and discrepancies are examined. Nearly all products reported a significant decreasing trend in the southern part of the Amazon River basin, whereas ZHA15 presented an upward trend over the entire basin, leading to the significant basin-scale increasing trend. ZEN14 reported the sharpest upward trend, more than $200 \mathrm{~mm} /$ year per decade, in the northwest of the basin. However, according to GLEAM and JUN10, Amazon experienced 
a remarkable ET decline in this region. Even between these two products, the estimates of the ET trend are different. The former reported a declining trend in the majority of the Amazon River basin, resulting in a significant downward basin-scale ET trend. By contrast, JUN10 presented a rising trend in the southeast, which neutralized the declining trend in the northwest.

In order to figure out the reason for the discrepancies between the ET estimates reported by the five global remote sensing ET products, four hypotheses were put forward to examine these products' capability to reflect the response of ET to different factors (brightening, warming, greening and deforestation). Details can be found in Sections 3.3-3.6.

\subsection{H1: Brightening Leads to Higher ET-Not Evident across Different Products}

By slope analysis and MK significance detection, it is found that brightening mainly occurred in the western parts of the Amazon River basin. Long-time series of ET in the brightening regions (ET bright $)$ and that over the buffer zone (ET bright_buf $_{\text {f }}$ from the five products were compared (Figure $6 b-f$ ).
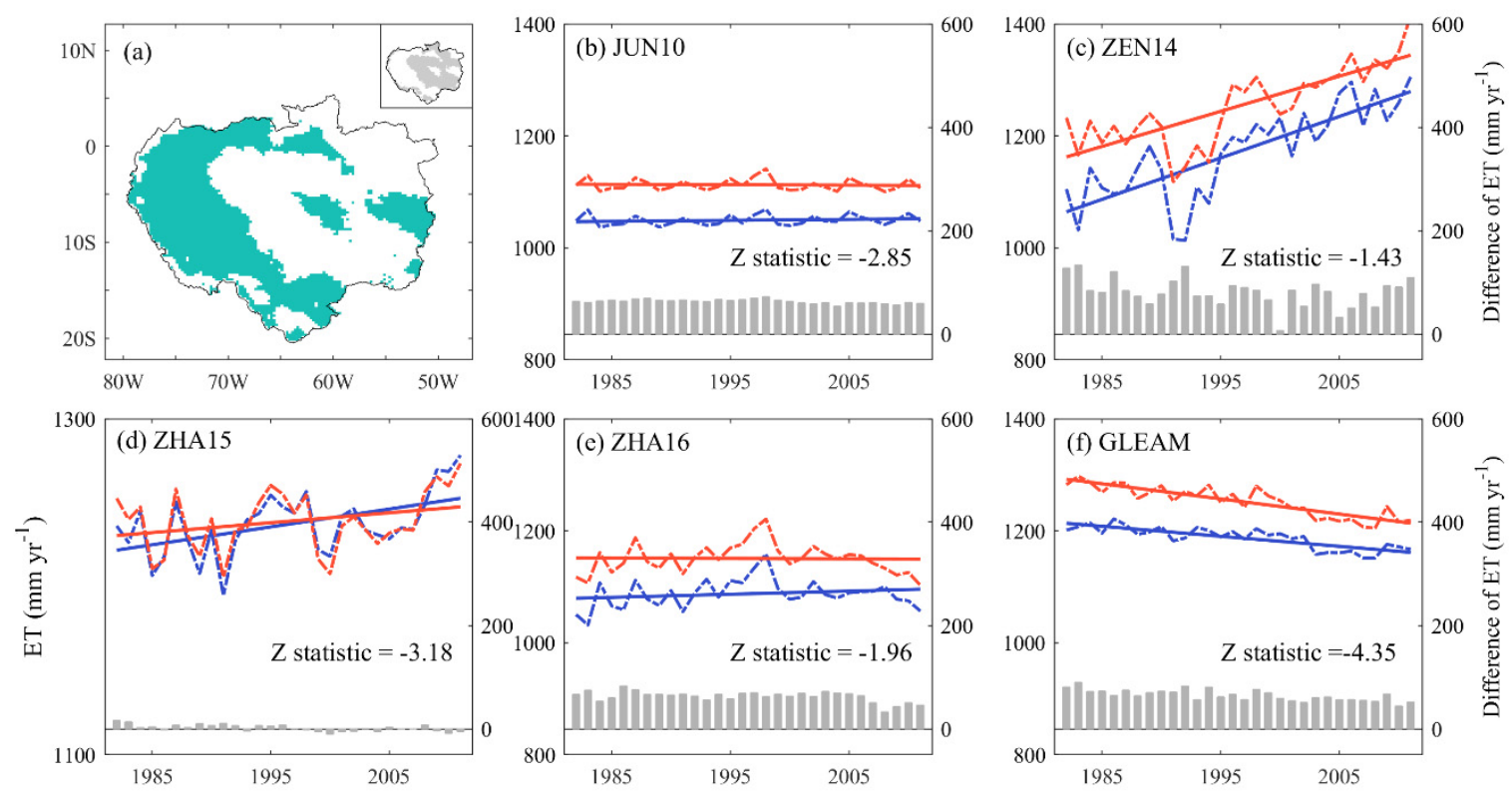

Figure 6. Response of ET to brightening. (a) Distribution of brightening regions in the Amazon River basin between 1982 and 2011 and the corresponding buffer zone (shown in the insert plot). (b-f) Annual average ET over the buffer zone (ET $T_{\text {bright_buf }}$, blue line) and that over the brightening regions ( $\mathrm{ET}_{\text {bright }}$, red line) were compared using five products. Grey bar is the difference between $\mathrm{ET}_{\text {bright }}$ and $\mathrm{ET}_{\text {bright_buf }}\left(\mathrm{ET}_{\text {bright }}\right.$ minus $\left.\mathrm{ET}_{\text {bright_buf }}\right)$. $\mathrm{Z}$ statistic is the $\mathrm{Z}$ value of the $\mathrm{MK}$ analysis of the difference.

Theoretically, brightening means less cloudiness and more sunlight, which lead to more photosynthesis. As a result, the time when the stomata are open is more, meaning more ET from transpiration. As $\mathrm{E}_{\mathrm{t}}$ dominates ET (more than 60\%) [52-54], its growth will increase ET.

According to this hypothesis, the gap between $\mathrm{ET}_{\text {bright }}$ and $\mathrm{ET}_{\text {bright_buf }}\left(\mathrm{ET}_{\text {bright }}\right.$ minus $\left.\mathrm{ET}_{\text {bright_buf }}\right)$ should be increasingly wider. However, as shown in Figure $6 b-f$, the differences reported by the five products are becoming significantly narrow, indicating that none of the products performed well in reflecting the response to brightening. This kind of misrepresentation may result from the driving factors chosen by different products. Four of the products, except for ZHA15, included precipitation as the forcing data of their algorithms. However, according to previous studies [1,22], net surface radiation, rather than precipitation, is the primary determinant of ET in the Amazon basin. The soil is always wet over the Amazon, meaning little influence on soil water moisture caused by precipitation. As for ZHA15, although it included radiation as an input, uncertainty still arises as the global net 
radiation product may have large uncertainty over the Amazon basin, where satellite precipitation products may reflect radiation better.

\subsection{H2: Warming Results in the Increase in ET-Evident in All Five Products}

By means of the same methods mentioned above, regions experiencing air temperature increase (warming) and decrease (cooling) were detected. As shown in Figures 7a and 8a, the majority of the Amazon River basin (the north-east) saw a statistically significant increase in the long-term annual air temperature, whereas only the southern part experienced a significant decline.
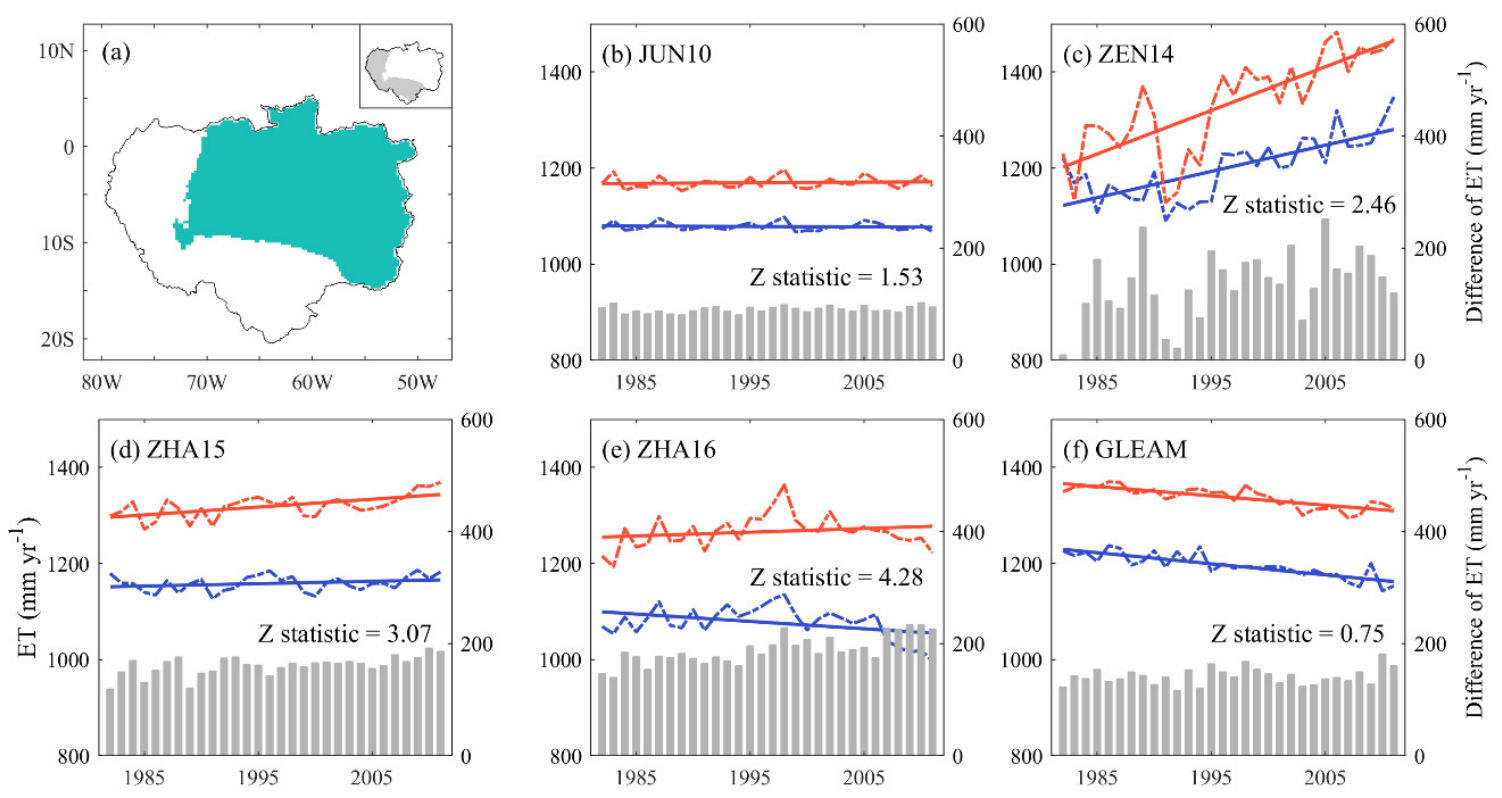

Figure 7. Response of ET to warming. (a) Distribution of the warming in the Amazon River basin during the period from 1982 to 2011 and the corresponding buffer zone (shown in the insert plot). (b-f) Annual average ET over the buffer zone $\left(\mathrm{ET}_{\text {warm_buf, }}\right.$ blue line) and that over the warming regions (ET $\mathrm{T}_{\text {warm, }}$ red line) were compared using five products. Grey bar is the difference between $\mathrm{ET}_{\text {warm }}$ and $\mathrm{ET}_{\text {warm_buf }}\left(\mathrm{ET}_{\text {warm }}\right.$ minus $\left.\mathrm{ET}_{\text {warm_buf }}\right)$. $\mathrm{Z}$ statistic is the $\mathrm{Z}$ value of the $\mathrm{MK}$ analysis of the difference.

The averaged ET over the warming regions $\left(\mathrm{ET}_{\mathrm{warm}}\right)$ and that over the corresponding buffer zone $\left(\mathrm{ET}_{\text {warm_buf }}\right)$ were compared. Obviously, the magnitude of the former was much larger than that of the latter, no matter which product was chosen (Figure $7 \mathrm{~b}-\mathrm{f}$ ). We further analyzed the trend of the difference between $\mathrm{ET}_{\text {warm }}$ and $\mathrm{ET}_{\text {warm_buf }}\left(\mathrm{ET}_{\text {warm }}\right.$ minus $\left.\mathrm{ET}_{\text {warm_buf }}\right)$. According to the $\mathrm{MK}$ analysis, a significant upward trend of the difference was detected according to ZEN14, ZHA15 and ZHA16, with $\mathrm{Z}$ values greater than $1.69(P<0.05)$. The other two products also presented similar trends, but the trends are not significant. That is to say, ET over the warming regions increased faster than ET over the buffer zone. This performance seems to be reasonable. In theory, with higher air temperature, evaporation intensified as water molecules can get more energy that allows them to escape from the liquid surface [55]. In addition, transpiration is also affected by air temperature. 

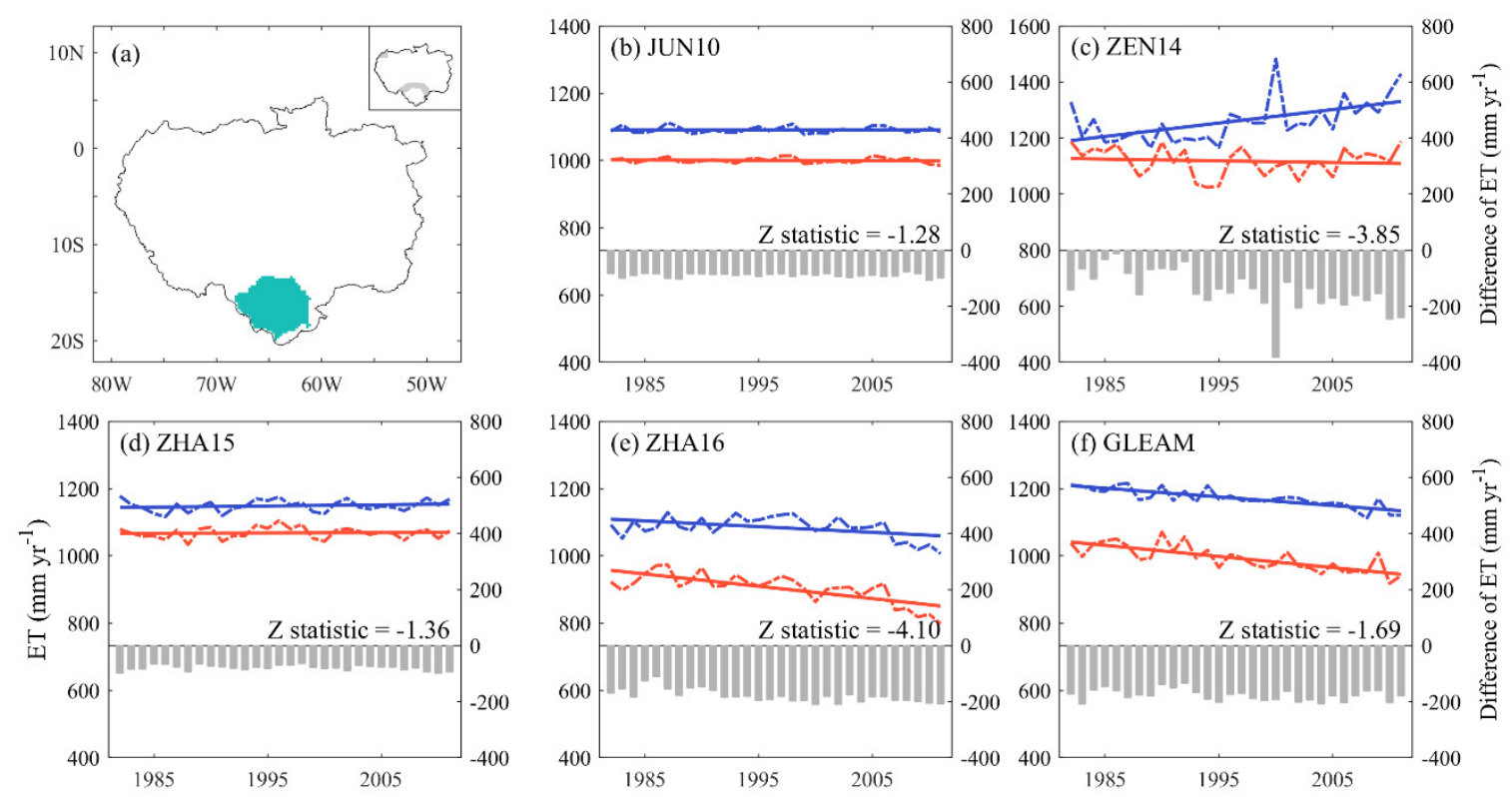

Figure 8. Response of ET to cooling. (a) Distribution of the air temperature decline in the Amazon River basin from 1982 to 2011 and the corresponding buffer zone (shown in the insert plot). (b-f) Annual average ET over the buffer zone (ET $\mathrm{ETool}_{\text {_buf }}$, blue line) and that over the air temperature -decline regions $\left(\mathrm{ET}_{\text {cool }}\right.$, red line) were compared using five products. Grey bar is the difference between $\mathrm{ET}_{\text {cool }}$ and $\mathrm{ET}_{\text {cool_buf }}\left(\mathrm{ET}_{\text {cool }}\right.$ minus $\left.\mathrm{ET}_{\text {cool_buf }}\right)$. $\mathrm{Z}$ statistic is the $\mathrm{Z}$ value of the $\mathrm{MK}$ analysis of the difference.

Using the same methods, we compared ET over the cooling regions $\left(\mathrm{ET}_{\text {cool }}\right)$ and its corresponding $\mathrm{ET}_{\text {cool_buf. }}$ It is clear that $\mathrm{ET}_{\text {cool }}$ was much lower than $\mathrm{ET}_{\text {cool_buf }}$ and the difference between these two is becoming larger (Figure $8 \mathrm{~b}-\mathrm{f}$ ), suggesting that ET over the cooling regions declined much more quickly than that over the corresponding buffer zone. It agreed well with our hypothesis that lower air temperature reduces ET. Overall, all five products can respond to the changes in air temperature.

It should be noted that factors influencing atmospheric evaporative demand are more than just air temperature. Generally speaking, higher air temperature, lower humidity, greater wind speed and lower pressure can all increase atmospheric evaporative demand [56]. In this case, if only air temperature was considered as the surrogate for atmospheric evaporative demand, uncertainty may arise and the product may overestimate the response of ET to warming [57]. However, the Amazon is a different thing. The canopy is too dense, so wind speed only influences the top of the canopy; relative humidity $(\mathrm{RH})$ is always "high", so it is also not a factor.

\subsection{H3: Vegetation Greening Promotes Increase in ET-Evident in Two Products}

Terrestrial vegetation is also an important determinant of terrestrial ET, which links soil moisture to the atmosphere through roots and leaf stomata [13]. Using the methods mentioned above, the area with a significant LAI increase was defined (greening). As shown in Figure 9a, greening is significant and extensive in the northern and western parts of the Amazon River basin, indicating that vegetation growth has significantly enhanced in these regions over the past 30 years. Many reasons may account for the increase in LAI, such as increasing $\mathrm{CO}_{2}$ fertilization effect, global warming, nitrogen deposition and land cover change [28]. 

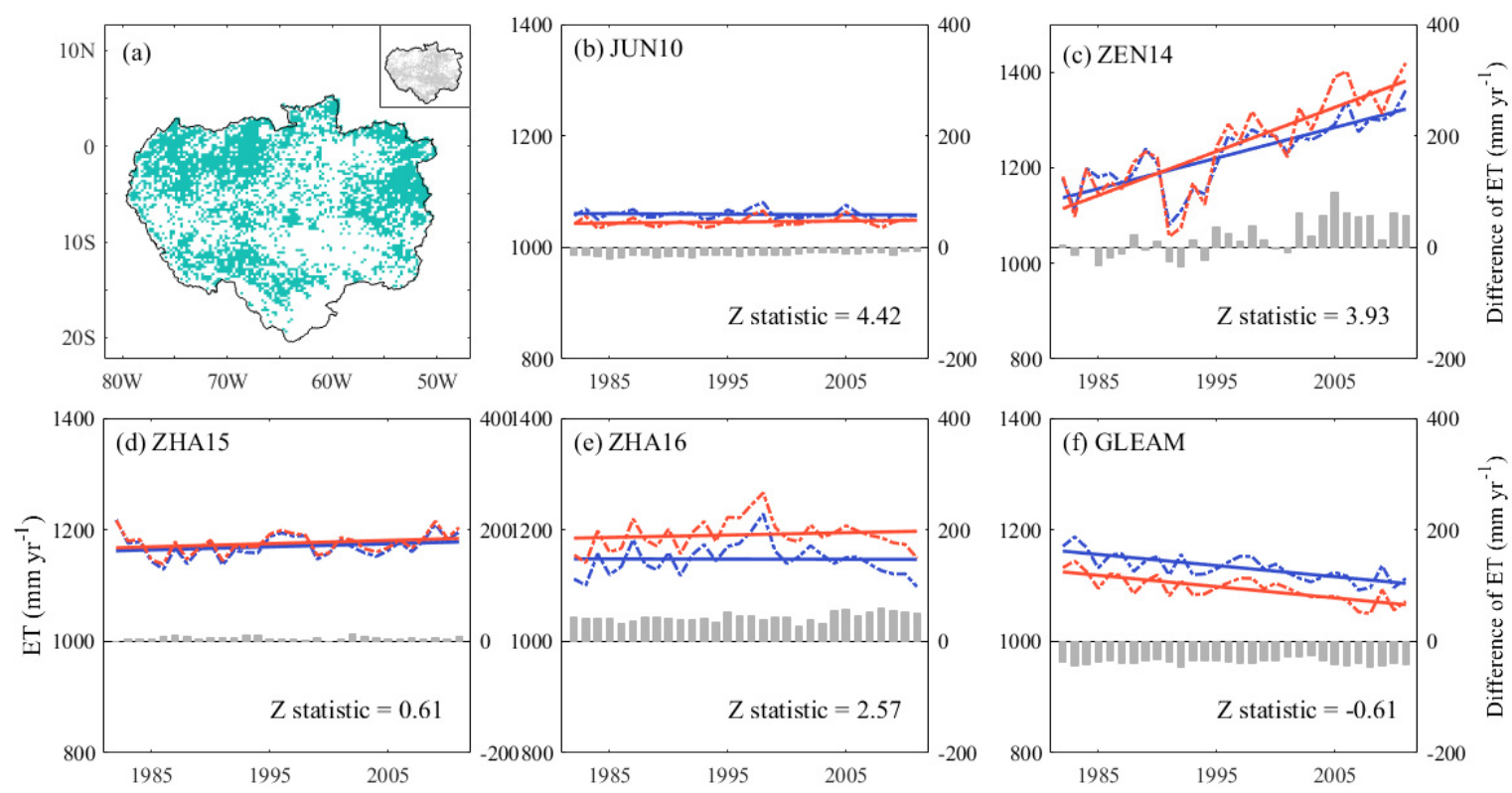

Figure 9. Response of ET to greening. (a) Distribution of greening in the Amazon River basin during the period from 1982 to 2011 and the corresponding buffer zone (shown in the insert plot).

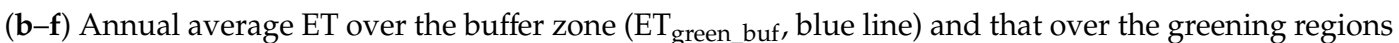
(ET $\mathrm{ET}_{\text {green }}$, red line) were compared using five products. Grey bar is the difference between $\mathrm{ET}_{\text {green }}$ and $\mathrm{ET}_{\text {green_buf }}\left(\mathrm{ET}_{\text {green }}\right.$ minus $\left.\mathrm{ET}_{\text {green_buf }}\right)$. $\mathrm{Z}$ statistic is the $\mathrm{Z}$ value of the $\mathrm{MK}$ analysis of the difference.

Long-time series of ET, in the greening regions ( $\left.\mathrm{ET}_{\text {green }}\right)$ and over the buffer zone (ET green_buf), from the five products were compared (Figure $9 \mathrm{~b}-\mathrm{f}$ ). In theory, vegetation greening may lead to higher $\mathrm{ET}$, as more vegetation means more leaf stomata, which enables more movement of water vapor and other gases through diffusion $\left(\mathrm{E}_{\mathrm{t}}\right)$ [58]. On the other hand, higher LAI also means more shading of the land surface, as well as less land-atmosphere connection [21], which may reduce the direct evaporation from the soil $\left(\mathrm{E}_{\mathrm{s}}\right)$. Due to the unclear understanding of the ET partitioning (the ratio of $\mathrm{E}_{\mathrm{t}}$ to ET), we cannot conclude that greening leads to higher ET directly. However, as $\mathrm{E}_{\mathrm{t}}$ dominates ET (more than 60\%) [52-54], we can assume that greening intensifies terrestrial ET. Based on this hypothesis, the difference between $\mathrm{ET}_{\text {green }}$ and $\mathrm{ET}_{\text {green_buf }}$ should become increasingly wider. As can be seen from Figure 9, only ZEN14 and ZHA16 presented such a trend, which demonstrated their capability to reflect the response of ET to greening in the Amazon River basin.

Nevertheless, it should be noted that apart from LAI, there are some other indices that can represent the changes in physiological characteristics of vegetation, such as the NDVI and fAPAR [43]. Almost all these global remote sensing ET products utilized only one or two indices, which may lead to a large discrepancy in our analysis. Specifically, ZHA15 used LAI as the vegetation driver, which is the same as the index used in this study. In contrast, JUN10 used fAPAR; ZEN14 and ZHA16 used NDVI. Despite the relatively better performance in reflecting the ET response to greening in this study, NDVI should be treated with caution when used in tropical areas. According to previous studies [59], NDVI has a limitation due to "saturation effect" in tropical areas, where vegetation is dense (LAI > 1). Under this circumstance, the reflectance of the red band remains insensitive and nearly unchanged with increased leaf area index. As a result, NDVI becomes saturated when the red band starts to saturate.

\subsection{H4: Deforestation Results in a Decrease in ET-Not Evident across All Five Products}

By comparing the land cover in the year 1992 and 2011, the deforestation area was defined. As can be seen from Figure 10a, deforestation mainly occurred in the southeastern part of the Amazon River basin. Many reasons may account for the extensive deforestation, such as cattle and soybean production and urbanization [28]. 

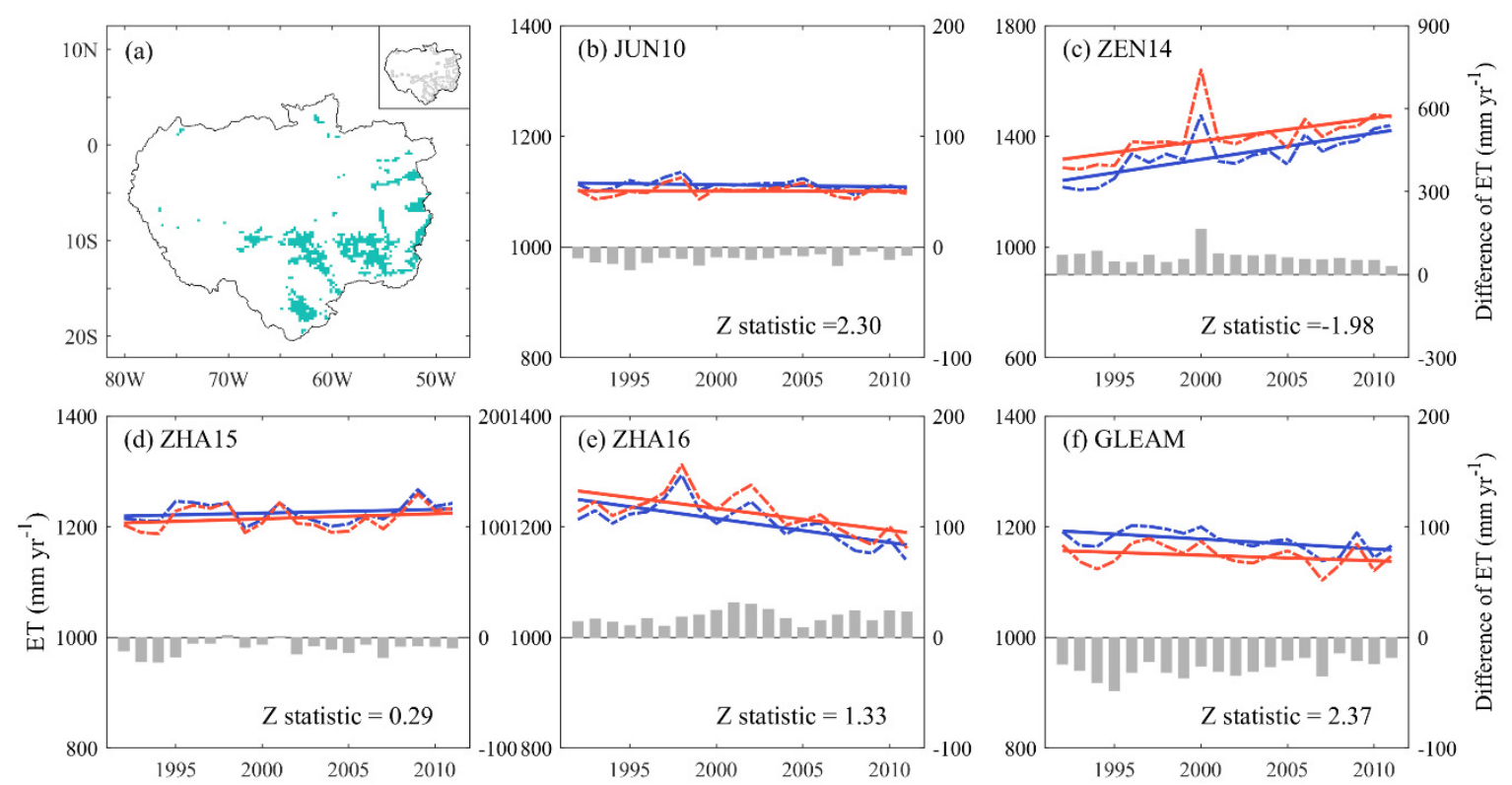

Figure 10. Response of ET to deforestation. (a) Distribution of deforestation in the Amazon River basin during the period from 1992 to 2011 and the corresponding buffer zone (shown in the insert plot). (b-f) Annual average ET over the buffer zone (ET $\mathrm{def}_{\text {debuf }}$, blue line) and over the deforestation regions $\left(\mathrm{ET}_{\mathrm{def}}\right.$, red line) were compared using five products. Grey bar is the difference between $\mathrm{ET}_{\text {def }}$ and $\mathrm{ET}_{\text {def_buf }}\left(\mathrm{ET}_{\text {def }}\right.$ minus $\left.\mathrm{ET}_{\text {def_buf }}\right)$. $\mathrm{Z}$ statistic is the $\mathrm{Z}$ value of the Mann-Kendall $(\mathrm{MK})$ analysis of the difference.

The number of deforestation pixels in the four stages were counted (Figure 11a). During the past 19 years, there were 687 pixels $\left(0.25^{\circ} \times 0.25^{\circ}\right)$ in total experiencing deforestation. To simplify the calculation, we treated $0.25^{\circ}$ as 25 kilometers and estimated the total deforestation area of $429,375 \mathrm{~km}^{2}$ (1992-2011). The result is in line with that of Eric et al. [24], which reported a deforestation area of $383,000 \pm 15,500 \mathrm{~km}^{2}$ from 1995 to 2017 . Besides, the deforestation rate in each stage is different, with the highest between 2003 and 2007. After 2008, deforestation slowed down, which may be explained by the policies implemented by Brazil in 2004, with the purpose of deforestation reduction and conservation promotion [25].
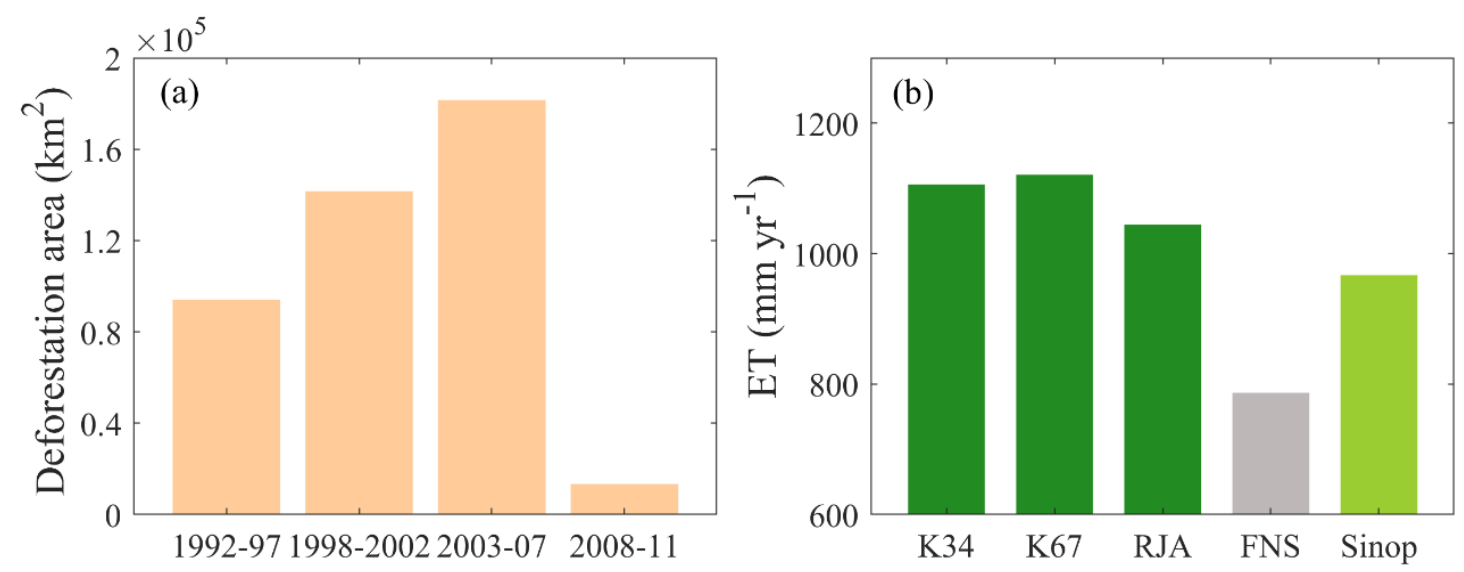

Figure 11. (a) Deforestation area in the four stages between 1992 and 2011 over the Amazon River basin. (b) Annual ET from the five eddy covariance sites.

Annual ET measured by EC sites were compared as well. As shown in Figure 11b, ET over the moist forest (K67) is highest, up to $1120 \mathrm{~mm} /$ year, followed by rainforest (K34, $1105 \mathrm{~mm} /$ year) and 
dry forest (RJA, $1043 \mathrm{~mm} /$ year). By contrast, ET of the semi-deciduous forest (Sinop) and pasture (FNS) are much lower, only 966 and $785 \mathrm{~mm} /$ year. In order to quantify the influence of deforestation on ET, we calculated the difference between the annual ET of forest and that of pasture as the effects of deforestation (conversion from "forest" into "pasture"). To simplify the calculation, we used the arithmetic mean of the moist forest, rainforest and dry forest as the mean annual ET of forest and the value is $1089 \mathrm{~mm} /$ year. The difference ( $304 \mathrm{~mm} /$ year) indicates that deforestation leads to the ET reduction of $304 \mathrm{~mm} /$ year per unit. The result is in agreement with Paca's finding, which showed that ET is highest for dense forests and much lower in bare areas and mosaic grassland [9]; land use converting from "forest" into "non-forest", such as field, agricultural, grazing, and secondary forests, reduces ET in the Amazon.

According to this theory, ET over the deforestation area $\left(\mathrm{ET}_{\mathrm{def}}\right)$ grows more slowly than that over the buffer zone ( $\left.\mathrm{ET}_{\text {def_buf }}\right)$, resulting in a larger gap between $\mathrm{ET}_{\text {def }}$ and $\mathrm{ET}_{\text {def_buf. }}$ As shown in Figure $10 \mathrm{~b}-\mathrm{f}$, the differences reported by the five products presented no such patterns. Besides, if the magnitude of the difference between $\mathrm{ET}_{\text {def }}$ and $\mathrm{ET}_{\text {def_buf }}$ was taken into consideration, we can conclude that none of these products performed well. As mentioned above, deforestation during the period 1998-2002 and 2003-2007 was more extensive, indicating a larger reduction in ET. However, none of these three remote sensing ET products can capture such a dynamic variation.

To conclude, no global ET reconstructions used in this study respond well to deforestation. It is probably because none of these remote sensing products truly took land cover change into account, although ZHA15 claimed that it considered the effect of land use and irrigation on ET by using the satellite-observed NDVI data, which can account for the effect of local perturbations to some extent [20]. This argument may not be completely correct, as NDVI can only represent the condition of the un-affected vegetation, rather than the conversion from forest to non-forest.

\section{Conclusions}

In this study, we investigated the reliability of global remote sensing ET products over the Amazon River basin. The magnitude of ET is evaluated using eddy covariance data at site level and using a water balance method at basin scale. At site level, the performances of these ET products are better over the forest sites than over the pasture site. As for the magnitude, at both site level and basin scale, JUN10 has the best performance, followed by ZHA16, highlighting the importance of local measurement in the ET reconstruction. However, as for the variability, JUN10 has largely underestimated the variation while ZEN14 overestimated it.

In terms of the long-term change, the five global ET reconstructions produced divergent ET trends over the past 30 years (i.e., ZEN14 and ZHA15, significant increase; GLEAM, significant decrease; JUN10, decrease, not significant; ZHA16, decrease after increase until 1998). In addition, the spatial distributions of ET and ET trends estimated by the five remote sensing products lack consistency.

In order to figure out the potential reason for the discrepancies between the ET estimates reported by the five global remote sensing ET products, four hypotheses were put forward to examine these products' capability to reflect the response of ET to different factors (brightening, warming, greening and deforestation). In general, these ET products respond better to warming and greening than to brightening and deforestation. The misrepresentation of ET response to deforestation may be explained by the fact that none of these five remote sensing products take the influence of deforestation into account. As for the specific product, ZEN14 and ZHA16 perform better, as they can respond well to three out of five factors (warming and cooling are treated as two different factors). Given the large uncertainties, the trend and pattern of ET over the Amazon River basin are still uncertain, which highlights the need for future tailored studies focusing on ET issues there.

There are a few points that deserve further study. First, GRACE data may be useful to improve the water balance method based estimate of ET by incorporating observations for the terrestrial water storage anomalies (TWSA). Second, updated precipitation and discharge reconstructions, as well as the ongoing flux tower observations, may be useful to evaluate and constrain the previous data-driven ET 
data sets. Besides, more spatial and temporal analyses will focus on the regions with different changes in precipitation, net radiation, and vegetation coverage and activity. With sufficient observation data, we will construct a regional water-balance-based ET model in South America. In addition, future work can use advances in downscaling that have resulted in high resolution soil moisture data sets using a combination of active and passive sensors [60,61] or visible and near infra-red sensors [62-64]. These high soil moisture data sets used in conjunction with meteorological inputs and hydrological models can help estimate evapotranspiration at high spatial resolution and temporal repeat. Yet, we believe this is a pilot study to highlight the divergent patterns of ET estimates across the Amazon River basin, upon which future refined analyses can be performed.

Author Contributions: Conceptualization, Z.Z.; methodology, Z.Z. and V.L.; formal analysis, J.W.; writing—original draft preparation, J.W.; writing—review and editing, V.L., P.L., M.P., X.C. and E.F.W.; visualization, J.W. and D.W.; supervision, Z.Z.; funding acquisition, Z.Z. All authors have read and agreed to the published version of the manuscript.

Funding: This research was funded by the start-up fund provided by Southern University of Science and Technology (no. 29/Y01296122) and Highlight Project on Water Security and Global Change of the Southern University of Science and Technology (SUSTech, Grant No. G02296302).

Acknowledgments: We thank Martin Jung, Ke Zhang, Yongqiang Zhang and Diego G. Miralles for providing long-term global remote sensing ET products covering the period 1982 to 2011 (JUN10, ZHA15, ZHA16 and GLEAM). We thank GPCC and NASA for providing rainfall data, and SO HYBAM for providing runoff data. Finally, we thank Joshua B. Fisher, Jin Wu, and George Vourlitis for providing EC data in the Amazon. We gratefully thank the anonymous reviewers for their critical comments and constructive suggestions on the manuscript.

Conflicts of Interest: The authors declare no conflict of interest.

\section{References}

1. Jung, M.; Reichstein, M.; Ciais, P.; Seneviratne, S.I.; Sheffield, J.; Goulden, M.L.; Dolman, A.J. Recent decline in the global land evapotranspiration trend due to limited moisture supply. Nature 2010, 467, 951-954. [CrossRef] [PubMed]

2. Bonan, G.B.; Doney, S.C. Climate, ecosystems, and planetary futures: The challenge to predict life in Earth system models. Science 2018, 359, 6375. [CrossRef] [PubMed]

3. Fisher, J.B.; Whittaker, R.J.; Malhi, Y. ET come home: Potential evapotranspiration in geographical ecology. Glob. Ecol. Biogeogr. 2011, 20,1-18. [CrossRef]

4. Spracklen, D.V.; Arnold, S.R.; Taylor, C.M. Observations of increased tropical rainfall preceded by air passage over forests. Nature 2012, 489, 282-285. [CrossRef] [PubMed]

5. Wang, K.; Dickinson, R.E. A review of global terrestrial evapotranspiration: Observation, modeling, climatology, and climatic variability. Rev. Geophys. 2012, 50, RG2005. [CrossRef]

6. Kool, D.; Agam, N.; Lazarovitch, N. A review of approaches for evapotranspiration partitioning. Agric. For. Meteorol. 2014, 184, 56-70. [CrossRef]

7. Karam, H.N.; Bras, R.L. Climatological basin-scale Amazonian evapotranspiration estimated through a water budget analysis. J. Hydrometeorol. 2008, 9, 1048-1060. [CrossRef]

8. Swann, A.L.S.; Koven, C.D. A direct estimate of the seasonal cycle of evapotranspiration over the Amazon River basin. J. Hydrometeorol. 2017, 18, 2173-2185. [CrossRef]

9. Paca, V.; Espinoza-Dávalos, G.E.; Hessels, T.; Moreira, D.M.; Comair, G.F.; Bastiaanssen, W.G. The spatial variability of actual evapotranspiration across the Amazon River Basin based on remote sensing products validated with flux towers. Ecol. Process. 2019, 8, 1-20. [CrossRef]

10. Billah, M.M.; Goodall, J.; Narayan, U.; Reager, J.; Lakshmi, V.; Famiglietti, J. A methodology for evaluating evapotranspiration estimates at the watershed-scale using GRACE. J. Hydrol. 2015, 523, 574-586. [CrossRef]

11. Lakshmi, V.; Small, E.E.; Hong, S.; Chen, F. The influence of the land surface on hydrometeorology and ecology: New advances from modeling and satellite remote sensing. Hydrol. Res. 2011, 42, 95-112. [CrossRef]

12. Lakshmi, V.; Fayne, J.; Bolten, J. A comparative study of available water in the major river basins of the world. J. Hydrol. 2018, 567, 510-532. [CrossRef] [PubMed]

13. Zeng, Z.Z.; Peng, L.Q.; Piao, S.L. Response of terrestrial evapotranspiration to Earth's greening. Curr. Opin. Environ. Sustain. 2018, 33, 9-25. [CrossRef] 
14. Mueller, B.; Hirschi, M.; Jimenez, C.; Ciais, P.; Dirmeyer, P.A.; Dolman, A.J.; Fisher, J.B.; Jung, M.; Ludwig, F.; Maignan, F.; et al. Benchmark products for land evapotranspiration: LandFlux-EVAL multi-data set synthesis. Hydrol. Earth Syst. Sci. 2013, 17, 3707-3720. [CrossRef]

15. Da Rocha, H.R.; Manzi, A.O.; Shuttleworth, J. Evapotranspiration. Geophys. Monogr. Ser. 2009, 186, $261-272$.

16. Betts, A.K.; Ball, J.H.; Bosilovich, M.; Viterbo, P.; Zhang, Y.; Rossow, W.B. Intercomparison of water and energy budgets for five Mississippi subbasins between ECMWF reanalysis (ERA-40) and NASA Data Assimilation Office fvGCM for 1990-1999. J. Geophys. Res. 2003, 108, 8618. [CrossRef]

17. Marengo, J.A. Characteristics and spatio-temporal variability of the Amazon River Basin Water Budget. Clim. Dyn. 2005, 24, 11-22. [CrossRef]

18. Zeng, N. Seasonal cycle and interannual variability in the Amazon hydrologic cycle. J. Geophys. Res. 1999, 104, 9097-9106. [CrossRef]

19. Huntington, T.G. Evidence for intensification of the global water cycle: Review and synthesis. J. Hydrol. 2006, 319, 83-95. [CrossRef]

20. Zhang, K.; Kimball, J.S.; Nemani, R.R.; Running, S.W.; Hong, Y.; Gourley, J.J.; Yu, Z. Vegetation greening and climate change promote multidecadal rises of global land evapotranspiration. Sci. Rep. 2015, 5, 15956. [CrossRef]

21. Zhang, Y.; Pena-Arancibia, J.L.; McVicar, T.R.; Chiew, F.H.S.; Vaze, J.; Liu, C.; Pan, M. Multi-decadal trends in global terrestrial evapotranspiration and its components. Sci. Rep. 2016, 6, 19124. [CrossRef] [PubMed]

22. Hasler, N.; Avissar, R. What Controls Evapotranspiration in the Amazon Basin. J. Hydrometeorol. 2007, 8, 380-395. [CrossRef]

23. Wild, M.; Gilgen, H.; Roesch, A. From Dimming to Brightening: Decadal Changes in Solar Radiation at Earth's Surface. Science 2005, 308, 847-850. [CrossRef] [PubMed]

24. Bullock, E.L.; Woodcock, C.E.; Souza, C.J.; Olofsson, P. Satellite-based estimates reveal widespread forest degradation in the Amazon. Glob. Chang. Biol. 2020, 26, 2956-2969. [CrossRef] [PubMed]

25. Malhi, Y.; Roberts, J.T.; Betts, R.A. Climate change, deforestation, and the fate of the Amazon. Science 2008, 319, 169-172. [CrossRef] [PubMed]

26. Baker, T.R.; Phillips, O.L.; Malhi, Y. Increasing biomass in Amazonian forest plots. Philos. Trans. R. Soc. Lond. Ser. B Biol. Sci. 2004, 359, 353-365. [CrossRef] [PubMed]

27. Huntingford, C.; Zelazowski, P.; Galbraith, D. Simulated resilience of tropical rainforests to $\mathrm{CO}_{2}$-induced climate change. Nat. Geosci. 2013, 6, 268-273. [CrossRef]

28. Zhu, Z.; Piao, S.; Myneni, R.B.; Huang, M.; Zeng, Z.; Canadell, J.G.; Cao, C. Greening of the Earth and its drivers. Nat. Clim. Chang. 2016, 6, 791-795. [CrossRef]

29. Zeng, Z.; Wang, T.; Zhou, F.; Ciais, P.; Mao, J.; Shi, X.; Piao, S. A worldwide analysis of spatiotemporal changes in water balance based evapotranspiration from 1982 to 2009. J. Geophys. Res. Atmos. 2014, 119, 1186-1202. [CrossRef]

30. Miralles, D.G.; Holmes, T.R.H.; De Jeu, R.A.M.; Gash, J.H.; Meesters, A.G.C.A.; Dolman, A.J. Global land-surface evaporation estimated from satellite-based observations. Hydrol. Earth Syst. Sci. 2011, 15, 453-469. [CrossRef]

31. Martens, B.; Miralles, D.G.; Lievens, H.; van der Schalie, R.; de Jeu, R.A.; Fernández-Prieto, D.; Beck, H.E.; Dorigo, W.; Verhoest, N. GLEAM v3: Satellite-based land evaporation and root-zone soil moisture. Geosci. Model. Dev. 2017, 10, 1903-1925. [CrossRef]

32. Mu, Q.; Heinsch, F.A.; Zhao, M.; Running, S.W. Development of a global evapotranspiration algorithm based on MODIS and global meteorology data. Remote Sens. Environ. 2007, 111, 519-536. [CrossRef]

33. Saleska, S.R.; da Rocha, H.R.; Huete, A.R.; Nobre, A.D.; Artaxo, P.; Shimabukuro, Y.E. LBA-ECO CD-32 Flux Tower Network Data Compilation, Brazilian Amazon: 1999-2006; Dataset; Oak Ridge National Laboratory Distributed Active Archive Center: Oak Ridge, TN, USA, 2013. Available online: http://daac.ornl.gov (accessed on 13 November 2019).

34. Vourlitis, G.L.; de Souza Nogueira, J.; de Almeida Lobo, F. Variations in evapotranspiration and climate for an Amazonian semi-deciduous forest over seasonal, annual, and El Niño cycles. Int. J. Biometeorol. 2015, 59, 217-230. [CrossRef] [PubMed]

35. Huffman, G.; Bolvin, D.; Braithwaite, D.; Hsu, K.; Joyce, R.; Xie, P. Integrated Multi-satellitE Retrievals for GPM (IMERG), Version 4.4; NASA's Precipitation Processing Center. 2014. Available online: ftp://arthurhou.pps.eosdis.nasa.gov/gpmdata/ (accessed on 31 March 2015). 
36. Schneider, U. GPCC Full Data Reanalysis Version 6.0 at $0.5^{\circ}$ : Monthly Land-Surface Precipitation from Rain-Gauges built on GTS-based and Historic Data. 2011. Available online: https://opendata.dwd.de/ climate_environment/GPCC/html/download_gate.html (accessed on 30 November 2019).

37. Schneider, U.; Becker, A.; Finger, P. GPCC's new land surface precipitation climatology based on quality-controlled in situ data and its role in quantifying the global water cycle. Theor. Appl. Climatol. 2014, 115, 15-40. [CrossRef]

38. Becker, A.; Finger, P.; Meyer-Christoffer, A. A description of the global land-surface precipitation data products of the Global Precipitation Climatology Centre with sample applications including centennial (trend) analysis from 1901-present. Earth Syst. Sci. Data 2013, 5, 921-998. [CrossRef]

39. Lin, P.; Pan, M.; Beck, H.E.; Yang, Y.; Yamazaki, D.; Frasson, R. Global reconstruction of naturalized river flows at 2.94 million reaches. Water Resour. Res. 2019, 55, 6499-6516. [CrossRef]

40. Copernicus Climate Change Service (C3S) (2019): C3S ERA5-Land Reanalysis. Copernicus Climate Change Service. Available online: https://cds.climate.copernicus.eu/cdsapp\#!/home (accessed on 3 July 2020).

41. Bowen, I.S. The ratio of heat losses by conduction and by evaporation from any water surface. Phys. Rev. 1926, 27, 779-787. [CrossRef]

42. University of East Anglia Climatic Research Unit; Harris, I.C.; Jones, P.D. CRU TS4.03: Climatic Research Unit (CRU) Time-Series (TS) Version 4.03 of High-Resolution Gridded Data of Month-by-Month Variation in Climate (Jan. 1901-Dec. 2018). Centre for Environmental Data Analysis Dataset. 2019. Available online: https://catalogue.ceda.ac.uk/uuid/10d3e3640f004c578403419aac167d82 (accessed on 24 December 2019).

43. Myneni, R.B.; Hoffman, S.; Knyazikhin, Y.; Privette, J.L.; Glassy, J.; Tian, Y.; Wang, Y.; Song, X.; Zhang, Y.; Smith, G.R.; et al. Global products of vegetation leaf area and fraction absorbed PAR from year one of MODIS data. Remote Sens. Environ. 2002, 83, 214-231. [CrossRef]

44. Zhu, Z.C.; Bi, J.; Pan, M. Global data sets of vegetation Leaf Area Index (LAI)3g and Fraction of Photosynthetically Active Radiation (FPAR)3g derived from Global Inventory Modeling and Mapping Studies (GIMMS) Normalized Difference Vegetation Index (NDVI3g) for the period 1981 to 2011. Remote Sens. 2013, 5, 927-948.

45. Fearnside, P.M. Deforestation in Brazilian Amazonia: History, rates and consequences. Conserv. Biol. 2005, 19, 680-688. [CrossRef]

46. ESA. Land Cover CCI Product User Guide Version 2. Technical Report. 2017. Available online: maps.elie.ucl.ac. be/CCI/viewer/download/ESACCI-LC-Ph2-PUGv2_2.0.pdf (accessed on 18 November 2019).

47. Mann, H.B. Non-parametric tests against trend. Econ. J. Econ. Soc. 1945, 13, 245-259.

48. Kendall, M.G. Rank Correlation Methods; Griffin: London, UK, 1975.

49. Maeda, E.E.; Ma, X.; Wagner, F. Evapotranspiration seasonality across the Amazon River basin. Earth Syst. Dyn. Discuss. 2017, 8, 439-454. [CrossRef]

50. Zhang, Y.; Pan, M.; Sheffield, J.; Siemann, A.L.; Fisher, C.K.; Liang, M.; Beck, H.E.; Wanders, N.; MacCracken, R.F.; Houser, P.R.; et al. A Climate Data Record (CDR) for the global terrestrial water budget: 1984-2010. Hydrol. Earth Syst. Sci. 2018, 22, 241-263. [CrossRef]

51. Pan, M.; Sahoo, A.K.; Troy, T.J.; Vinukollu, R.K.; Sheffield, J.; Wood, E.F. Multisource estimation of long-term terrestrial water budget for major global river basins. J. Clim. 2012, 25, 3191-3206. [CrossRef]

52. Jasechko, S.; Sharp, Z.D.; Gibson, J.J.; Birks, S.J.; Yi, Y.; Fawcett, P.J. Terrestrial water fluxes dominated by transpiration. Nature 2013, 496, 347-350. [CrossRef]

53. Good, S.P.; Noone, D.; Bowen, G. Hydrologic connectivity constrains partitioning of global terrestrial water fluxes. Science 2015, 349, 175-177. [CrossRef]

54. Lian, X.; Piao, S.L.; Huntingford, C. Partitioning global land evapotranspiration using CMIP5 models constrained by observations. Nat. Clim. Chang. 2018, 8, 640-646. [CrossRef]

55. Brutsaert, W. Hydrology: An Introduction; Cambridge University Press: Cambridge, UK, 2005.

56. Rui, X.F. Evaporation and Transpiration. In Principles of Hydrology, 6th ed.; China Water Power Press: Beijing, China, 2013; pp. 122-126.

57. Sheffield, J.; Wood, E.F.; Roderick, M.L. Little change in global drought over the past 60 years. Nature 2012, 491, 435-438. [CrossRef]

58. Katul, G.G.; Oren, R.; Manzoni, S.; Higgins, C.; Parlange, M.B. Evapotranspiration: A process driving mass transport and energy exchange in the soil-plant-atmosphere-climate system. Rev. Geophys. 2012, 50, RG3002. [CrossRef] 
59. Asner, G.P.; Scurlock, J.M.O.; Hicke, J.A. Global synthesis of leaf area index observations: Implications for ecological and remote sensing studies. Glob. Ecol. Biogeogr. 2003, 12, 191-205. [CrossRef]

60. Narayan, U.; Lakshmi, V.; Jackson, T. High resolution change estimation of soil moisture using L-band radiometer and radar observations made during SMEX02 experiments. IEEE Trans. Geosci. Remote Sens. 2006, 44, 1545-1554. [CrossRef]

61. Narayan, U.; Lakshmi, V. Characterizing sub-pixel variability of low-resolution radiometer derived soil moisture using high resolution radar data. Water Resour. Res. 2008, 44, 06425. [CrossRef]

62. Fang, B.; Lakshmi, V.; Bindlish, R.; Jackson, T.; Cosh, M.; Basara, J. Passive Microwave Soil moisture downscaling using vegetation index and surface temperature. Vadose Zone J. 2013, 12, 1-19. [CrossRef]

63. Fang, B.; Lakshmi, V.; Bindlish, R.; Jackson, T. Downscaling of SMAP soil moisture using land surface temperature and vegetation data. Vadose Zone J. 2018, 17, 1-15. [CrossRef]

64. Fang, B.; Lakshmi, V.; Jackson, T.; Bindlish, R.; Colliander, A. Passive/active microwave soil moisture change disaggregation using SMAPVEX12 data. J. Hydrol. 2019, 574, 1085-1098. [CrossRef]

(C) 2020 by the authors. Licensee MDPI, Basel, Switzerland. This article is an open access article distributed under the terms and conditions of the Creative Commons Attribution (CC BY) license (http://creativecommons.org/licenses/by/4.0/). 